\title{
前腕部屈伸運動の再現性について
}

\section{永田宠北本拓**室増男*** \\ A STUPY ABOUT MOTOR-RETENTION ON THE FLEXION AND EXTENSION OF THE FORE-ARM}

\author{
Akira Nagata, Hiraku Kitamoto and Masuo Muro
}

\begin{abstract}
The purpose of this study is to clarify the characteristics of the short-term motormemory and to analyze various loads effect of motor-retention in the exercise of flexion and extension of the fore-arm. As the means of analysis, correlation function between command and response waves was used efficiently and furthermore the electric computer system helped to investigate motor-retention. Many experimental conditions were decided to $0.1-0.8 \mathrm{~Hz}$ of one's exercise rhythm, 0-0.5 kg of loads attached to the fore-arm, and $3-6 \mathrm{~cm}$ of exercise displacement. Three healthy persons were employed as subjects.

As the results of this study, following points were shown clearly.

(1) After the fore-arm was exercised to the flexuous and extensional directions for $25 \mathrm{sec}$, response waves of motor-retention were recorded to Data-recorders for 60 sec.. Quantitative analysis of this motor-retention became effective by using the method of correlation function.
\end{abstract}

(2) About exercise rhythm (frequency), the rapidity of fore-arm exercises in the retentive learning was $0.05 \mathrm{~Hz}$ slower than that of these exercises in the begining learning.

(3) About the transfer gain of these exercises between command and response waves, two motor-gains of the retentive and begining learning were shown the same values only when these exercises were practised at experimental conditions of $0.8 \mathrm{~Hz}$ frequency and $0.5 \mathrm{~kg}$ load.

(4) Motor-retention rate, that was calculated from error values of performance, was dropped down such as about 0.3 rate in proportion to the time elapsed of recollection and also to rhythm-slownes of the command frequency.

(5) Optimal exercise displacement of the fore-arm was proved to the median of 6 and $3 \mathrm{~cm}$ in order to reappear the length memorized by the begining learning.

(6) Discharged voltages of the integrated EMG in Flexor and Extensor Carpi Radialis were recorded lower at the time, when motor-retention was displayed rightly and exactly.

(7) Sychological reminiscence and this motor-retention were shown quite opposite results in the learning points of reaction time, rhythm, strength and displacement, because the former was dependent upon the memory in the central nervous system (brain cortex), while the latter relied upon the memory in the peripheral-nervous system (receptor).

\section{(J. Physical Fitness Japan 1976, $25: 71 \sim 77$ )}

\section{I. 緒}

運動学羽の上達や熟練度を評価, 考察する時に 一度学羽した事項を上手に再現する能力，即ち一
種の部憶状態の濃淡を利用するととが多い。運動 学習に記憶の占める範囲は大きく，習熟過程にお ける重要なファクターを示して翼熟の遅速にも大 きな影響をおよぼしている。

\section{* 東京都立大学理学部体育学教室 Tokyo Metropolitan Univ.}

** 国学院大学文学部体育研究室 Kokugakuin Univ.

*** 東京都立墨田川高等学校 Sumidagawa High School 
再生，あるいは記憶学㥜に関する心理学的な诟 究2)3(4)5(6)10)12)1322129332) は多くみられるが，筋力 や運動の発現様相から検討した砸巟1114)26)27)はほ とんどなく, 速動の効果器, 受谷器を中心にし て, 身体这動全体の短時開の記憶に関する報告は 見当らない。

運動学装中, 技術のみの習熟過程の山でも指導 者によって教授され，師籁された近動パターンや フォームを学習し，それを洀び， ある将間経過後 に再現し，その型が指導者のものと学羽者のもの とが一致すれば優秀な教育者であり，のみこみの 早い生徒とい执る。この教授さ机た少項を再生: するという課程が日常きわめて多くの指学体系の 中で使われ，常に再現性の高い, 憶の磪立を求め る壦合が多い。著者らはこのような運動技術の㿟 得の桹否に関する能力を運動心理学的な “把持”

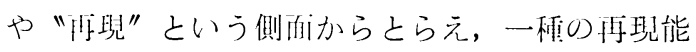

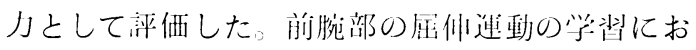
いて, ショートターム・メモリー ${ }^{20123)}$ を小心に

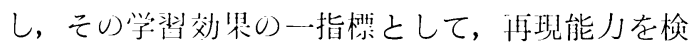

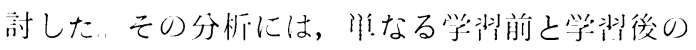
成績の比較に留まらず，遇動曲線の椂相やパタ一 ンを電子・胡算機による相閨関数法によって比挍し た。運動の羽熟過利におけるシステムアナリシス によって，連動学消能力の坫本要素である再抯に ついて基本的なモデル実験をおてない, 検討した 絬果を提分するものである。あくまでも，失験空

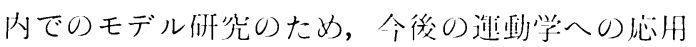
ひために点礎尖験资料を提供するものである。

\section{II. 実 験 方 法}

\section{1. 届伸運動学習システム}

第 1 困のようなブロック線忷によって，㤛腕激

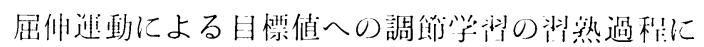
関する総合的な逃動システムが慣成されると考え た。视觉系を子な情報受行器とし, 中枢, 脊䯣神

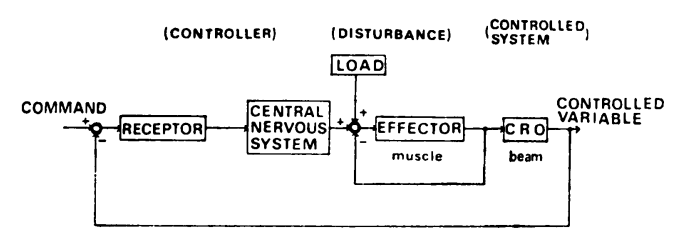

Fig. 1 Block diagram in the exercise of flexion and extension
経系を調節部，前腕部の筋肉系を操作部，オッシ ログラフ上の波沜を制御対象とした。前腕部の屈 伸運動による日慓波形の追跡中に急激に目樌波形 のみを視覚上から消失させ，その後も屈伸運動を 持続させて, 目愞波形の消失後の応答変化から前 牌部の再現状態を検討した。

\section{2. 実験条件}

再現状態を测定するための実験脳が第 2 汹であ り，一婳のモデル実験を設定した。実験姿勢とし ての前腕部屈伸速動は，上体を固定した椅座位姿 勢で，时関節を支点とし，手掌部を作用点とする 屈伸運動である。㐬腕部の動き（応答）は, 線形 ポテンショ・メータを通して電圧变抁されて, 視 営系のフィードバック情報としてブラウン管オッ シログラフ上に線分表示した。

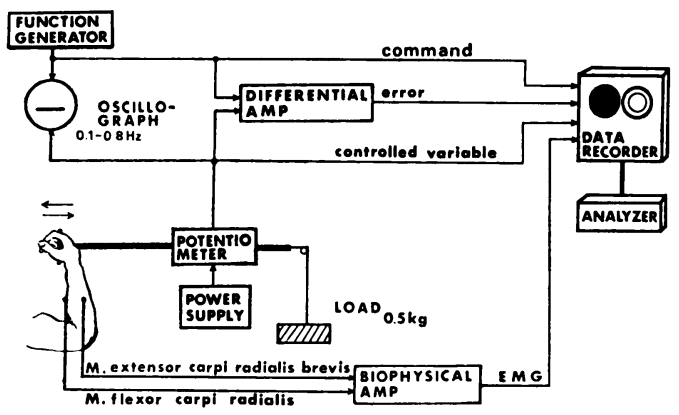

Fig. 2 Experimental chart

目際波形（正弦波）がオッシログラフ上に表示 されている状態（25 sec 閌）での鼓腕部による屈

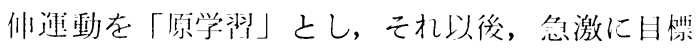
波沜をオッシログラフ上より消失させた状態（60

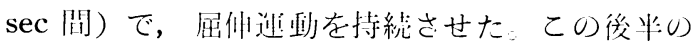

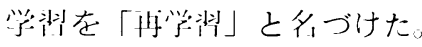

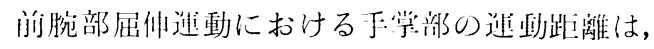

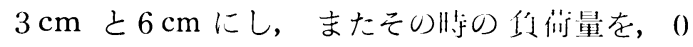

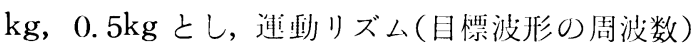
を0.1，0.2，0.4，0.8Hz の注波形とし，それ ぞ扎を組み令才せて唎した。オツシログラフと被 検者の甘の趾離は, $30 \mathrm{~cm}$ である。被検者は, 22 〜26才の男子 3 名で, 们腕長約 $30 \mathrm{~cm}$, 部腕屈曲 力約 $25 \mathrm{~kg}$ とほぼ等しかった。

\section{3. データ処理方法}

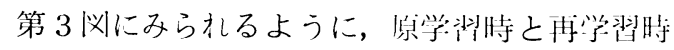

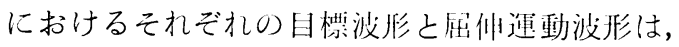




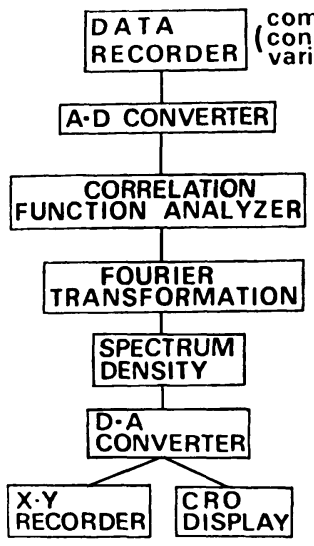

Fig. 3 Block diagram of analysis

データ・レコーダに集録し，そのデータを $\mathrm{A}-\mathrm{D}$ 変換する。さらに時間产: $\tau$ の闒数である両者の相 関関数 (相互相関関数) $\phi_{x y}(\tau)=\lim _{\mathrm{T} \rightarrow \infty} \frac{1}{\mathrm{~T}} \int_{0}^{\mathrm{T}}$ $\mathrm{x}(\mathrm{t}) \mathrm{y}(\mathrm{t}+\tau) \mathrm{dt}^{\mathrm{8})}$ をフーリエ変換した。すなわち周 波数領域から，振幅を中心にクロス・スペクトラ 么密度

$$
\begin{aligned}
\Phi_{x y}(\mathrm{f}) & =\int_{-\infty}^{\infty} \phi_{x y}(\tau) \mathrm{e}^{-2 \mathrm{rj} \pi} \mathrm{d} \tau^{8)} \text { を求めた。 } \\
\mathrm{x} & : \text { 目標(入力)波形 } \\
\mathrm{y} & : \text { 屈伸運動(出力)波形 } \\
\mathrm{t} & : \text { 測定時間 } \\
\tau & : \text { サンプリングタイム } \\
\mathrm{T} & : \text { 最大测定時間 } \\
\mathrm{f} & : \text { 周波数 }
\end{aligned}
$$

この值を D-A 変換して, XY レコーダに書かせ た。そのクロス・スペクトラム密度（振幅）が最 高に表示された综の周波数を算出し，乙れを良好 な再現状態の運動りズムとした。（第 4 四参照） た，その侍の振幅值を生体が発挥した再現状態の 利得（ゲイン）とした（第 5 四参照）。

原学㑭時之再学習時のそれぞれにおける目愠波 比に対する屈伸運動波形のずれを偏差量として算 出し, 原学習洔の偏差量と再学習時の偏差量との 此率を把持率 ${ }^{29)}$ (Retention Rate) とした。

$$
R . R=\frac{E_{L}-E_{R}}{E_{L}} \times 100
$$

EL：原学桨時の偏差量

$\mathrm{ER}_{\mathrm{R}}$ : 再学垍時の偏差量

上式を求め, 運動の正確な成績の面から連動パタ ーンの再現状態を検討した（第 6 図参照）。

\section{III. 結 \\ 果}

\section{1. クロス・スペクトラムからみた再現状態の変化}

1）再学刲時の運動周波数

第 4 図は，目標周波数に対する再現状態をク口 ス・スペクトラム密度振幅が最高に表現された時 の楇波数からま之めたものである（図は 3 人の被 検者の代表的な例として示した。
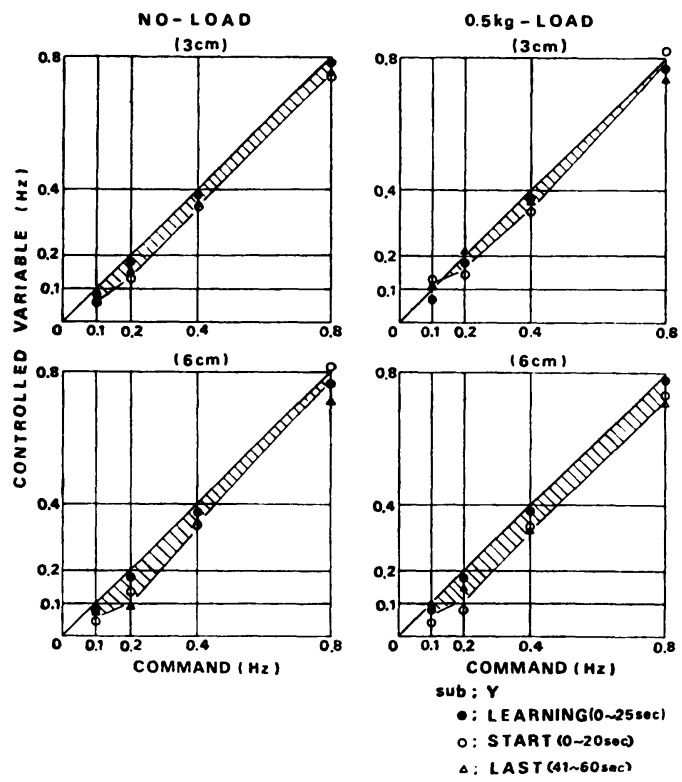

Fig. 4 Comparision with motor-rhythm in the case of the begining learning and retention

; motor-rhythm in the begining learning

$\bigcirc$; motor-rhythm in the start point of retention

$\triangle$; motor-rhythm in the last point of retention

vertical axis ; frequency in the subjects response

transversal axis ; frequency in the command

屈化運動将の負荷量や運動距離の各種の実験条 件の変化に対して，原学習時では，目標波形の周 波数に屈伸通動波形の周波数が一致する傾向があ り，0.1，0.2，0.4，0.8Hz と屯に，正確な運動 がみられた。しかし，乙れに対して，再学習時で は，0〜20sec と 41〜61sec の両時開带において， 目慓周波数より $0.05 \mathrm{~Hz}$ (約 $200 \mathrm{msec}$ ) 遅いリズ ムの再現となり，時間経過とともに序々に遅くれ の見象がみられた。また，目標速動リズムが早く 
なるにしたがって，そのリズムに近い屈伸運動リ ズムが再現された。

2）再学畾時の禹動振幅（密度）

第 5 図は,クロス・スペクトラム密度（振幅） の最高值を各目慓䦌波数ごとにまとめたものであ る。原学剹时, 再学習時ともに連動距離が $3 \mathrm{~cm}$ から $6 \mathrm{~cm}$ と 2 倍になると，振幅の再現状態に約 $5 \mathrm{~dB}$ の增加がみら机た。 $0.8 \mathrm{~Hz}$ の早い運䣦リズ ムになると，原学装猔に近い振幅の再現がみられ た。

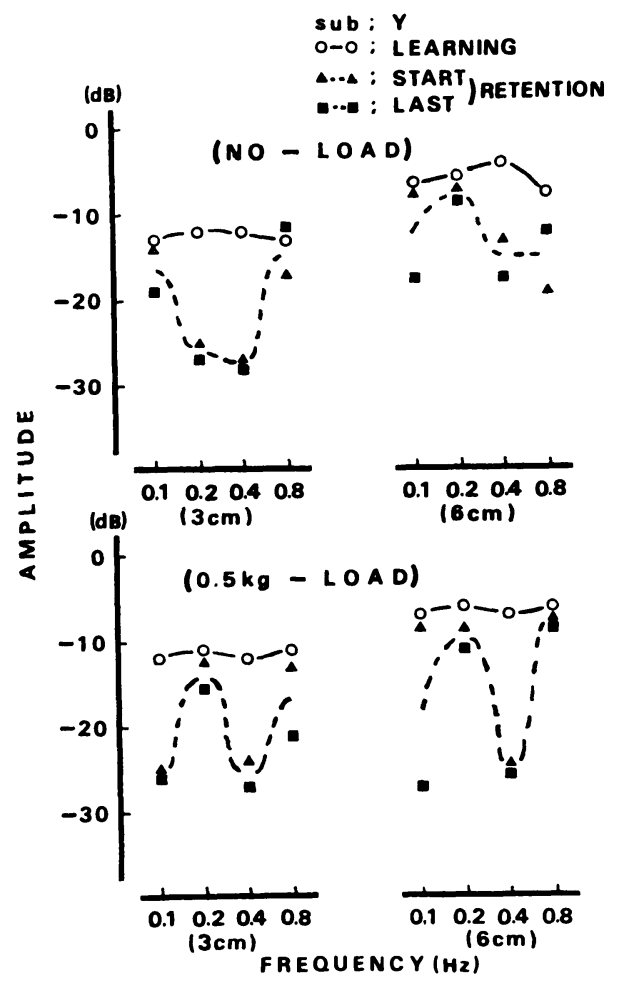

Fig. 5 Changes of motor-gain (amplitude) in the begining learning and retention

\section{2. 各種実験条件による再現状態の変化}

\section{1）敒攸甼の变化}

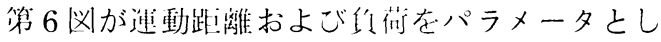

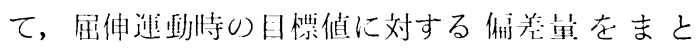

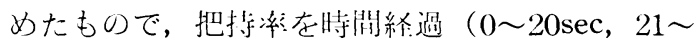
40sec, 41〜60 sec）ごとにプロットしたものであ

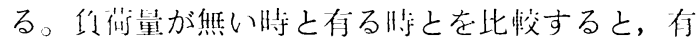
る時の方が約 $2 \% 0$ 制合で情現の揞加がみら机 た。

2）琎動践灕（屈们的度）の变化

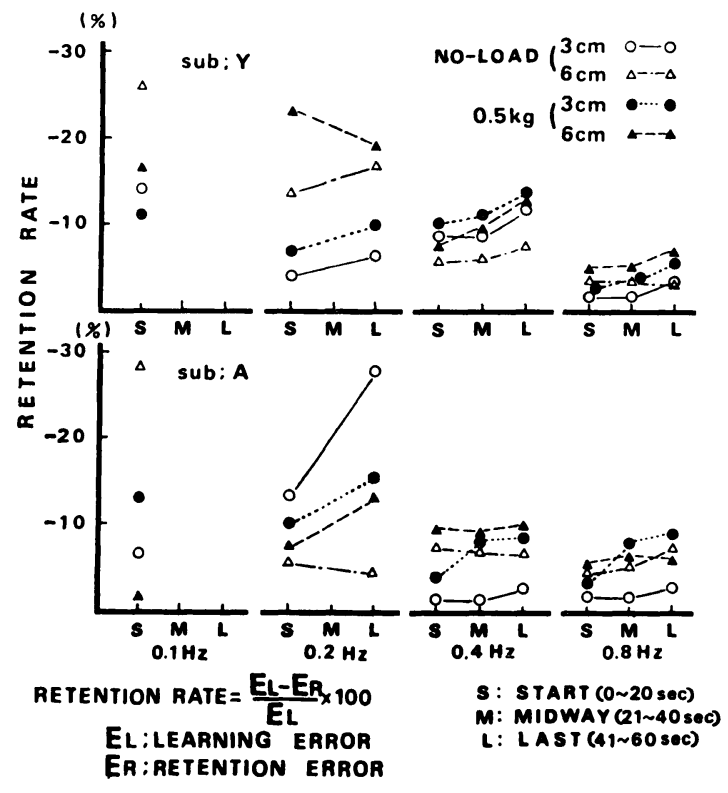

Fig. 6 Changes of retention rate according to the time elapsed, command frequency, loads and exercise displacement

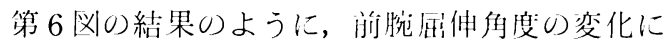

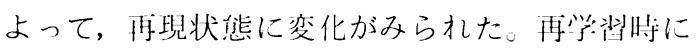
連政距離が $6 \mathrm{~cm}$ から $3 \mathrm{~cm}$ と $1 / 2$ になると把持摔 は，約 1.5 倍の问上がみら机た。

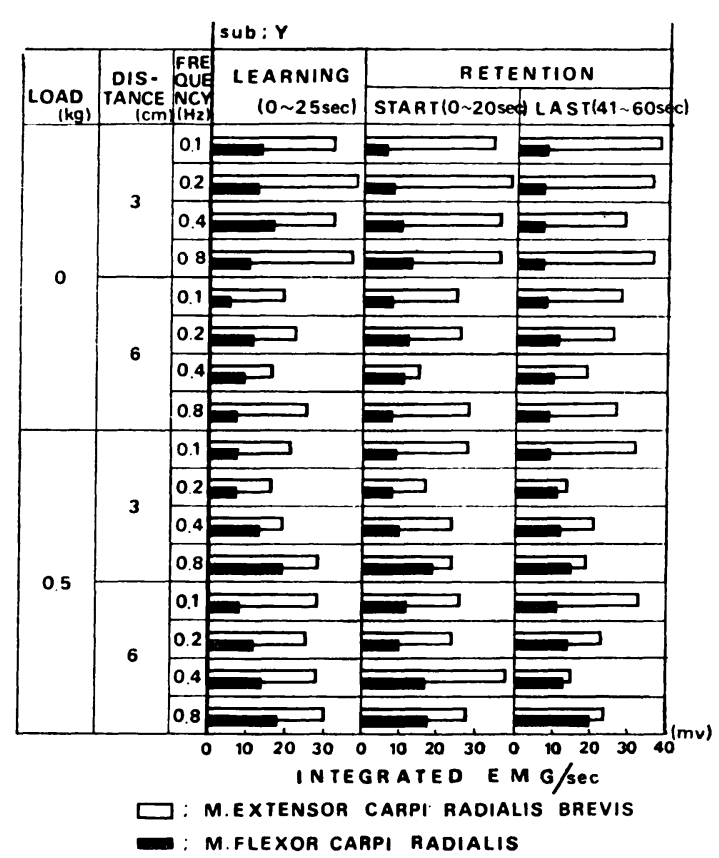

Fig. 7 Changes of the integrated EMG in the begining learning and retention 


\section{3. 時間経過による再現状龍の変化}

第 6 四の結果のように, 各種実験条件（迎動リ ズム, 距離, 負荷量) に执いて, 時閒経過ととも に，把持率の比例的な減少がみられた。しかし， 早い運動リズムの場合は，時間が経過しても把持 率の频著な減少はみられなかった。

\section{4. 筋放電量の再現状態の変化}

第 7 図は, 前腕部の短橈側手根伸筋之樘側手根 屈筋の秥分竻放電量を原学習時之再学習時の時間 経過（0～20sec，41～60sec）でとにまとめたもの

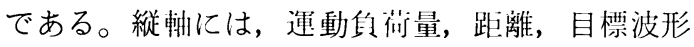
の周波数等の実験条件をプロットした。横軸に は，積分筋放笔量をプロットした。すべての実験 条件で，伸筋の放兒量が屈朌の約 1.5 2 倍の值 を示した。目想波形の凮波数（速動りズム）が早 くなるとともに，屈筋の放電鱼は比例的な增㞦が

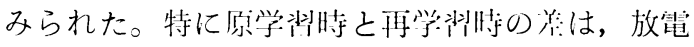
量に関して，有意な差がみられなかった。

\section{IV. 考察}

\section{1. 屈伸運動成績とパターンからみた再現性について}

60秒間之いう短時間後の再生運動にもかかわら

ず，原学畒時より，再学装時の再玩パターンで は，約15％の把掉泙の低下がみられた。こ机は，

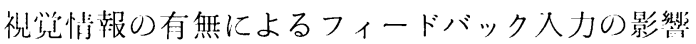
が大きいと思われる。そして，入力だけをブラウ ン行よにみせ，人開の制御結果を全然表示しない オープン・ループ・トラッキングの場合と類似し た結果を示した。これらの結果は，人間内部のフ ィードバック㙨檴による制御が主に関与 ${ }^{15)}$ し、末 梢系の諸器官にショート・ターム・メモリーの存 在を知る指垱になるのではないかと考えられる。 今回の実験のショート・ターム・メモリーに対し て, 従来の憶, 再牛:奏験のロング・ターム・メ モリ一は，より如実に林梢系よりも川枢系の竹:用 が問題とされていた。

運動リズム(目杪凰波数)が早くなるとともに， 此例的に再現状態が向上している。造いリズムの $0.1 \mathrm{~Hz}$ と速い $0.8 \mathrm{~Hz}$ の場合を比較すると, 約 2 倍の把掉率の增加がみられた。他方, 連栗成績の

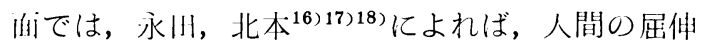
速動調節では， $0.8 \mathrm{~Hz}$ のリズムが臨界追従周波数 であると㫰:している。本論文の主題となる再現
性は, 速い連動リズムは,タイミング制御に近くな り，記憶による制御運動より屯，筋反射的24)25)な 運動制御でおてなわれている結果 ${ }^{28)}$ と考えられ る。また, 屈曲, 伸展の速度制御には, 筋紡鍾の 求心性神経 G II が有効に働いているという報告1) からも，速い運動リズムに対する反射的な回路が 情成され，末梢部のフィードバック・ループによ る適碓な逃動が叮能となり ${ }^{9)}$ ，学習の再現性の向 上がみられるようになる。こうした背景が本論文 の $0.4 \mathrm{~Hz}$ と $0.8 \mathrm{~Hz}$ の運動りズムに優れた再現状 態を示したととを裹付けるものである。

運動距離が 2 倍になると，生:体の運動利得（ゲ イン，または速動機能の高まり）の增加が倍增し た。これは，筋肉系の高まりが，迎動距離の增大 とともに著明になるものと考えられる。迎動移動 量や強度と生体の利得变化は，かなり比例的な関 係をもつが，今回の実験では，必ずしも鈔的な 比例関係ではなかった。遇動りズム（日愣咸波数） の再見状態に比較して, 連動利得の再现性は，か なり良好な一致の状態を示した。特に，0.5kg の 负倾の場合，原学㥜時之変わら奴生体の利得値 (-10〜 - 8dB) を示した。乙れは,リズム的な 速度り再现よりも，量的な振幅の再現性が高く， 论意の掉続を亦すものである。このととは、ショ ート・ターム・メモリ一将の筋感覚系を中心とし た木梢系の、愢にも関係すると思われる。

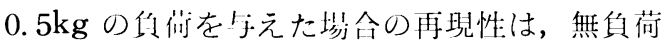
の状態に比らべて約 2 \%のの増加となった。これ は，把持率としての佔には，統計上の有意着はな くても，舟学翼初期において，若けの问上がみら れたてとを亦すもので， $0.5 \mathrm{~kg}$ という侦衐，即ち 重量によって再見性が艮くなることは，䇟の重量 感覚系が関与しているととを㱔付けるものであ

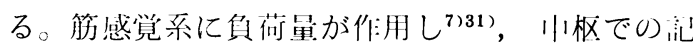
憶素子と合わせて，再現状態の改善を促したもの と考えられる。

知汃い運動距離の $3 \mathrm{~cm}$ に有効な再現状態がみ られた。この現貨は，随意運動の再現特性では， 速度が速いと変位も大きく，速度が荤いと変位が 小さくなるといわれ，本論本でも前述の運動リズ ム博梘特性とともに確認されている。また，視覚 情報を切断すると生:体の变位量が減少する ${ }^{19}$ ) 特徵 もみられた。運動距離の減少は，位置制御システ 
ムの問題であり，速動制御の意識レベル下におけ る閉ループ・サーボシステムとして働くようであ る。このシステムの大きなフィードバックは，主 に関節受容器からの情報に基づき, 関䬣の间有器 官が運動距離の知覚と学習過程に決定的な役制を 果たしている22)。そのため，乙の屈他迎動の再現 性には,より一層, 未梢系の器官が献係している と思われる。

ショート・ターム・メモリーに拈ける心理学的 な学習実験では, 学消腈後よりも一定侍間経過し たときの方に再現性が问上している。特に分散的 練装よりも集中的練洦においてレミニセンスが生 じやすいという報告20)30)がある。しかし，本実験 では集川的練侨であるにもかか扔らず，レミニセ ンスとは反刘の椂相を呈した。すなわち中枢，あ るいは，そ机に類似した記憶が十分になされなか ったてとをホしているものと推祭される。このモ デル実験においては，彷来の定義による「䛉憶」 ではなく，木梢感覚系への表面的刺激の絬果であ

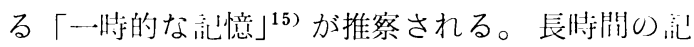
憶として残るためには，原学㥜の時開を $25 \mathrm{sec}$ か ら 2 〜 倍に延ばさねばならないと思打机る。

\section{2. 生体反応からみた再現状態}

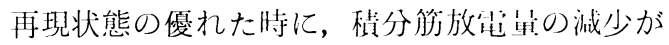
みられた。これは, 屈伸道動の効果器としての管肉 系が低い興畕状態で速動を叮能にしていることを 示し，熟練者と术熟練者を比夥した沙熟過积にお いて同一筋群から0筋放㫣量が減少するという報

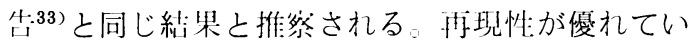
ることは，筋肉系り汗動を低くおさえ，安定な状 態で一定り繰り这し速卧を速続させることを意味 する。そして，一析けパターン認識やモデル制御 に移行した禹動パターンを小すものである。

また，连俥りズムの增㧈とともに，屈筋の筋放 芯思に比例的な增大がみられたが，乙机は，良好 な惊見状態と屈筋の放䉓量間に相関があるといえ る。屈仲運動の筋の協調状態は, 屈筋と伸筋の划: 抗様相から評価されるが, 永田, 北本の報告:17)19 にもあるように，前腕部の进動での筋放笔は，仙 筋が屈筋よりも約 2 倍の放電量を示し， 今川の先 験でも同じ結果が示さ机た。

\section{V. 要}

前腕部の 屈伸運動による原学習をおてなった 後, ショート・タームな運動の再現学習を実施 し, 前腕部（末梢部）を中心とする運動再現特性 の基礎資料を得た。運動りズム, 负侕量, 運動距 離等の条件变化による再現状態への影筲を検討 し, データーの相関関数的解析方法によって以下 のような結果を得た。

1. 前腕部の屈伸婵動の再現状態の価には, 原学習時と再学習時の運動パターンの相関関数的 手法が有効で, 定量的に解析可能となった。

2. 末梢部を中心とした再学洦でのショート・ ターム・メモリーは心理学的研究の言語, 記憶学 装におけるロング・ターム・メモリ一時に生じる レミニセンスと反対の㥞相である。

3. 迎動リズムの再見には, 目愫りズムより遅 いリズム，即ち全间波数時の值を平均して約 0.05 $\mathrm{Hz}$ のおくれを生じた。

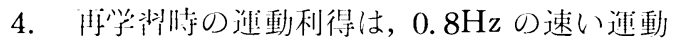

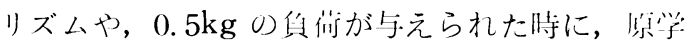

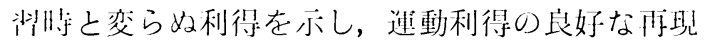
性を小した。

5. 把持率（偏美率）よりみた再现状態は，訬

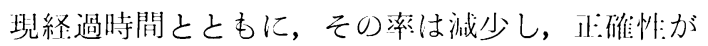
低くなった。また，再学畒時の速動リズムが 0.1 $\mathrm{Hz}$ から $0.8 \mathrm{~Hz}$ と速くなるに良がって, 目㥍りズ ムに合致した再現連動りズムがあられれ，適磼な 再現状態がみられた。

6. 屈伸通動距離を知かくすると将现性は, 问 上するが, 䛉憶上の车適な此離は, $6 \mathrm{~cm}$ と $3 \mathrm{~cm}$ のほぼ中開と考えられた

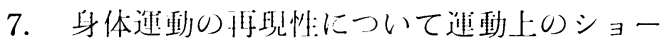
ト・ターム・メモリーの站埸から考察を㞦え，玩 埸への忘用の基儊资料を得た

(丞付昭利 51 年 5 月 11 日)

\section{參 考 文 献}

1）少汒啓造，梶山三郎，藤井克彦(1973)：バイオ メカニズム 2, 初版, 神経一筋制御系のシミュ レーション, 東京大学出版公, 東京, 71-81

2) Bunch, M.E., (1941) : The measurement of retention by the relearning method, Psychol. Rev., 48, 450-456.

3) Bunch, M.E.,(1941) : A comparison of retention and transfer of training from similar 
material after relatively long intervals of time, J. comp. Psychol., 32, 217-231.

4) George, F.H., (1952) : Errors of visual recognition, J. exp. Psychol., 43, 202-206.

5) Gordon, H. B., (1974)：学消の理論（下), 2 版, 学兒上保持の基本的条件, 㴼風館 東京, 464-496.

6）芳賀 純(1969)：講座心理学, 第; 7 觉, 初版, 保持之忘却, 来京大学出版会, 東京, 122-140.

7）畠山一灭，永四 昆，三枝木泰文(1971）：筋固 有反射系の自動例御理論仢解析, 计测的動制御 学会論文集，8，389-397.

8) 石井 泰(1973): 测定值の統計的処理, 3 版, 信号処理, 電気孚公, 東京, 83-155.

9）加藤一郎, 浜田利满, 㚣滕邦明, 守明川我吅 (1973)：バイオメカニズム 2 , 初版, 人间機械 システムにおける矨電栌韩と電気刺激フィード バック, 東京大学出版会, 東宗, 236-242.

10) Katona, G., (1940) : Organizing and memorizing, New-York Columbia University Press, 18-20.

11) Kimble, G.A., and Bilodeau, E.A., (1949): Work and rest as variables in cyclical motor learning, J. exp. Psychol., 39, 150-157.

12) Luch, C.H., (1922): The condition of retention, Psychol. Monogr., 31-142.

13) Mary, L, N., (1968) : Short-term memory trace decay in kinesthetically monitored force reproduction, The Research Quarterly, 39, 640-646.

14) Merrill, J. M.,(1971) : Effects of overlearning on the retention of a gross motor skill, The Research Quarterly, 42, 60-69.

15）三木英雄，原敬，橾本考之，泗川俊门， (1972)：予知追跡汶御における制御者の制御特 性:関する一考察, 計测白動制御学会論文身, 8, 406-413.

16）永川昆, 北本 拓(1974)：脚筋力による持続 迎従速動の解析，体力科兴，23，134-143.

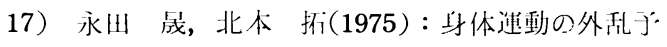
測能力に関する基礎的研究，体育学研究，20, 269-279.

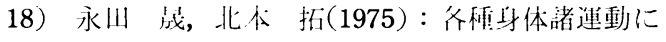
よる前腕部细波数応答特性の变化, 人間工学, 11, 97-98.

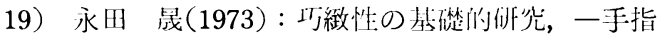

描写速動の多変量町関分析一，日本体育協会ス ポーツ科学研究報告, IV, 24-33.

20) Peacock, J.B., (1972): A method for the investigation of interpolated information and time effects in short term retension, Ergonomics, 15, 701-704.

21) Postman, L., and Phillips. L.W. (1963) : The effects of variable context on the acquisition and retention of paired associats, Amer. J. Psychol., 66, 511-519.

22) Radonjic, D., and Long, C., (1973)：続人间の 于足の制御，初版，なぜ筇電制御はむずかしい か, 学献社, 東京, 54-63.

23) Richard, A. S., and Kenneth, M. A., (1970) : Intertrial intervals and motor short term memory, The Research Quarterly, 41, 432438.

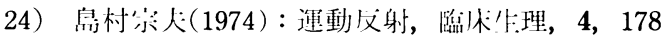
-183 .

25）島村宗人(1974)：反射の生理，脳上神絴，26， $33-41$.

26）管 弘之(1968）：記憶されてた㳡意迎耐の再現特 性について, 人间工学, 4, 237-238.

27) Tomlinson, R.W. (1972) : Control impedance and precision of feedback as parameters in sensorimotor learning, Ergonomics, 15, 3347.

28）土屋和犬(1972)：任体の速動機構とその制御, 初版，追跡動作の分析，杏林書院，東宗，303325.

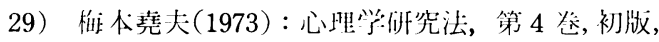

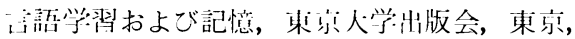
105-157.

30）梅扫分三，宮城音弥，相良次次，依出 新，

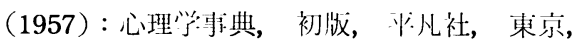
671.

31) Voduvnic, L., Kralz, A., Kelsim, D., and Brovsak, M., (1973)：人閂の手足の制御, 3 版, 電父䏀激による筋運動のシミュレーション, 学献社, 東宗, 14-29.

32）八木 笔(1972)：現代心理学入㺫第 8 \%， 5 版，想起上忘却，岩波書店，東索， 125-138.

33）川下謙智，高术公三郎，阔本 勉(1971）：鉄棒 運動に招ける順手車輪の筋電図学的研究, 体育 学研究, 15, 93-102. 